\title{
KEDUDUKAN TANAH WAKAF YANG DIKUASAI AHLI WARIS
}

\author{
Aurelia Nadya Pricilia Tjung \\ Magister Kenotariatan, Fakultas Hukum, Universitas Airlangga Surabaya \\ e-mail: nadyatjung1@gmail.com \\ Debby Eka Kartikasari \\ Magister Kenotariatan, Fakultas Hukum, Universitas Airlangga Surabaya \\ e-mail: debby.eka95@gmail.com \\ Choiryzha Rochmatul Hilma \\ Magister Kenotariatan, Fakultas Hukum, Universitas Airlangga Surabaya \\ e-mail: choiryzha_hilma@yahoo.com
}

\begin{abstract}
ABSTRAK
Penelitian yang berjudul "Kedudukan Tanah Wakaf Yang Dikuasai Ahli Waris" ini bertujuan untuk lebih dalam mengetahui dan memahami serta menganalisis bagaimana kedudukan tanah wakaf yang telah bersertipikat namun masih dalam penguasaan ahli warisnya. Metode penelitian yang digunakan adalah penelitian secara Normatif. Penelitian secara Normatif yaitu penelitian dengan menggunakan pendekatan perundang-undangan dan menarik asas-asas hukum yang berkaitan dengan tanah wakaf, sertipikat wakaf dan ahli waris dari wakif. Berdasarkan hasil penelitian ini dapat disimpulkan bahwa, Pertama, Tanah milik yang telah diwakafkan oleh wakif kepada nazhir harus dilakukan secara tertulis yang mana tertuang dalam Akta Ikrar Wakaf (AIW) yang dibuat oleh PPAIW, yang kemudian harus didaftarkan kepada BPN untuk mendapatkan sertipikat tanah wakaf sebagai tanda bukti wakaf. Kedua, Dengan adanya sertipikat tanah wakaf tersebut, maka kedudukan nazhir terlindungi dan telah memiliki kekuatan hukum sehingga tidak dapat digugat oleh ahli waris. Terlebih lagi dalam Pasal 3 UU No. 41 Tahun 2004 telah ditegaskan bahwa wakaf tidak dapat dibatalkan, sehingga ahli warisnya pun tidak dapat menggugat tanah tersebut. Kata Kunci: Wakaf; Sertipikat Tanah Wakaf; Kedudukan Ahli Waris
\end{abstract}

\section{ABSTRACT}

The research entitled The Position of a Waqf Owned by Heirs aims to more deeply know and understand and analyze how the position of the waqf land has been certified but is still under the control of the heirs. The research method used is Normative research. Normative research is research using a statutory approach and attracting legal principles relating to waqf land, waqf certificates and heirs from wakif. Based on the results of this study, it can be concluded that, First, Owned land that has been represented by wakif to nazhir must be done in writing which is contained in the Pledge Act of Endowments $(A I W)$ made by PPAIW, which must then be registered with the BPN to obtain the waqf land certificate as proof of waqf. Second: With the existence of the waqf land certificate, then nazhir's position is protected and has legal powers so that it cannot be sued by heirs. Moreover, in Article 3 of Law No. 41 of 2004 it has been stated that the waqf cannot be canceled, so that the heirs cannot sue the land.

Keywords: Waqf; Sertificate of Waqf Land; Heirs Position 


\section{PENDAHULUAN}

Wakaf merupakan suatu lembaga keagamaan yang memiliki fungsi sosial dan merupakan salah satu fungsi ibadah kepada Allah. Dalam praktik masyarakat saat ini wakaf memiliki hubungan secara fungsional dengan pemecegahan masalah sosial dan kemanusiaan. Di mana salah satunya yaitu umat Islam melaksanakan wakaf yang mana digunakan untuk kegiatan keagamaan seperti membangun masjid. Fungsi dari wakaf adalah untuk mengekalkan manfaat tanah yang diwakafkan. Hal demikian itu merupakan manifestasi dari ajaran Agama Islam, di mana dalam sebuah hadist Rosululloh SAW yang diriwayatkan oleh Muslim dari Abu Hurairah yang terjemahannya: "Apabila mati anak Adam, maka terputuslah daripada seluruh amalnya keculi tiga hal yaitu shodaqoh jariyah, ilmu yang bermanfaat, dan anak sholeh yang mendoakan kedua orangtuanya." Imam Muslim meletakkan hadist ini dalam bab wakaf karena para ulama menafsirkan istilah shodaqoh jariyah dengan wakaf. ${ }^{1}$

Indonesia sendiri memiliki salah satu tujuan yaitu memajukan kesejahteraan umum sebagimana tercantum dalam pembukaan Undang-Undang Dasar 1945. Bersangkutan dengan hal tersebut dilaksanakan oleh umat Muslim melalui wakaf, yang mana mengembangkan potensi yang terdapat pada lembaga keagamaan yang memiliki manfaan ekonomis. Wakaf di Indonesia sendiri diatur dalam Pasal 49 ayat (3) Undang-Undang Nomor 5 Tahun 1960 tentang Peraturan Dasar Pokok-Pokok Agraria yang mana menyebutkan bahwa perwakafan tanah milik yang dipergunakan untuk kepentingan peribadatan sepanjang dipergunakan sesuai tujuannya dalam bidang keagamaan akan dilindungi oleh peraturan pemerintah. Atas dasar pasal tersebutlah diciptakan Peraturan Pemerintah Nomor 28 Tahun 1977 tentang Perwakafan Tanah Milik yang mana dalam PP tersebut mengatur mengenai tata cara dan pendaftaran perwakafan tanah milik. Sedangkan dalam UndangUndang Nomor 41 Tahun 2004 tentang Wakaf dalam penjelasan angka 1 ditegaskan bahwa perbuatan hukum wakaf wajib dicatat dan dituangkan dalam Akta Ikrar Wakaf (AIW) didaftarkan di Pengadilan Agama dan juga harus diumumkan. Dan terakhir wakaf diatur dalam Peraturan Pemerintah Nomor

\footnotetext{
${ }^{1}$ Adijani Al-Alabij. (1989). Perwakafan Tanah di Indonesia Jakarta: Rajawali Press, h. 25.
}

25 Tahun 2018 tentang Perubahan atas Peraturan Nomor 42 Tahun 2006 tentang Pelaksanaan UndangUndang Nomor 41 Tahun 2004 tentang Wakaf. Pada dasarnya dalam semua peraturan tersebut diatur mengenai pemanfaatan harta benda wakaf sesuai dengan fungsinya yang mana salah satu manfaatnya yaitu manfaat ekonomis harta benda wakaf tersebut untuk kepentingan ibadah dan juga memajukan kesejahteraan umum.

Sedangkan untuk kapan lahirnya wakaf, menurut Hukum Islam perwakafan lahir seketika itu juga saat adanya pernyataan pihak yang mewakafkan harta benda miliknya. Hal berbeda terjadi menurut hukum positif. Di mana pelaksanaan wakaf harus dilakukan dengan ikrar yang dibuat di hadapan Pejabat Pembuat Akta Ikrar Wakaf (PPAIW) dan dua orang saksi serta harus dibuat dalam bentuk Akta Ikrar Wakaf(AIW). ${ }^{2}$ Hal tersebut seperti yang tercantum dalam Pasal 9 ayat (1) PP No. 28 Tahun 1977 menyebutkan bahwa pihak yang hendak mewakafkan tanahnya diharuskan datang dihadapan PPAIW untuk melaksanakan Ikrar Wakaf. PPAIW dalam hal ini yaitu Kepala KUA Kecamatan. Apabila suatu kecamatan tidak memiliki kantor KUA, maka Kepala Kantor Wilayah Depatemen Agama menunjuk Kepala KUA terdekat sebagai PPAIW di kecamatan tersebut.

Sejalan dengan hal tersebut PPAIW selaku pembuat AIW sendiri memiliki kewajiban melaksanakan tugas-tugas antar lain: ${ }^{3}$

1. Menyelenggarakan AIW dengan terlebih dahulu melakukan hal-hal berikut: a. Meneliti kehendak wakaf; b. Meneliti dan mengesahkan nazhir; c. Meneliti saksi ikrar wakaf; d. Menyaksikan pelaksanaan ikrar wakaf; dan e. Membuat AIW.

2. Menyampaikan AIW dan salinannya selambatlambatnya dalam jangka waktu satu bulan setelah dibuatnya;

3. Menyelenggarakan AIW;

4. Menyimpan dan memelihara AIW dan daftarnya;

5. Atas nama nazhir PPAIW diharuskan mengajukan permohonan kepada Bupati/Walikotamadya Kepala Daerah setempat untuk mendaftarkan tanah milik tersebut.

\footnotetext{
${ }^{2}$ ibid.

${ }^{3}$ Juhaya S. Praja. (1995). Perwakafan di Indonesia Sejarah Pemikiran Hukum dan Perkembangannya. Bandung: Yayasan Piara, h. 5.
} 
Selain Pasal 9 ayat (1) PP No. 28 Tahun 1977, pelaksaan ikrar wakaf juga diatur dalam Pasal 17 UU No. 41 Tahun 2004, yang mana isinya:

1. Ikrar wakaf dilaksanakan oleh Wakif (pihak yang mewakafkan harta benda miliknya) kepada nazhir (pihak yang menerima harta benda wakaf dari wakif guna dikelola dan dikembangkan sesuai dengan tujuan sebenarnya) dihadapan PPAIW dengan disaksikan oleh 2 (dua) orang saksi.

2. Ikrar Wakaf sebagaimana dimaksud pada ayat 1 dinyatakan secara lisan dan/atau tulisan serta dituangkan dalam akta ikrar wakaf oleh PPAIW.

Dalam Pasal 18 undang-undang tersebut menyebutkan pelaksanaan wakaf apabila wakif berhalangan hadir. Yang mana isinya: dalam hal wakif tidak dapat menyatakan ikrar wakaf secara lisan atau tidak dapat hadir dalam pelaksanaan ikrar wakaf karena alasan yang dibenarkan oleh hukum, wakif dapat menunjuk kuasanya dengan surat kuasa yang diperkuat oleh dua orang saksi. Untuk dapat melaksanakan ikar wakaf, wakif atau kuasanya menyerahkan surat dan/atau bukti kepemilikan harta benda wakaf kepada PPAIW.

Tujuan adanya AIW yaitu untuk mencegah dan menghindari sengketa tanah wakaf yang akan terjadi antara wakif dan nazhir, maupun antara keluarga wakif (ahli waris) dan nazhir. Akta Ikrar Wakaf tersebut digunakan sebagai bukti dari perbuatan wakaf tersebut. Tapi ternyata pada faktanya AIW yang telah didaftar di Pengadilan Agama saja tidak cukup dalam pembuktian wakaf. Sehingga saat ini di Indonesia masih banyak terdapat permasalahan seputar wakaf, khususnya tanah sebagai objek wakaf. Oleh karena itu, AIW saja tidak cukup. Menurut Pasal 32 UU No. 31 Tahun 2004 dengan AIW, tanah wakaf tersebut harus didaftarkan oleh PPAIW atas nama nazhir agar menjamin perlindungan hukum dan kepastian hukum mengenai keabsahan tanah wakaf tersebut, sebagaimana dimaksud oleh Peraturan Pemerintah Nomor 24 Tahun 1997 tentang pendaftaran tanah. Tanah wakaf tersebut didaftarkan pada Instansi yang berwenang, yang mana dalam hal ini merupakan kewenangan Kantor pertanahan setempat atau Badan Pertanahan Nasional (BPN). ${ }^{4}$

${ }^{4}$ H. Taufik Hamami. (2003). Perwakafan Tanah (Dalam Hukum Agraria Nasional). Jakarta: Tatanusa, h. 153.
Dalam Pasal 12 ayat (1) PP Nomor 42 Tahun 2006 juga telah menyebutkan bahwa nazhir wajib mengadministrasikan, mengelola, mengembangkan, mengawasi, dan melindungi harta benda wakaf. Yang mana hal itu dilakukan dengan cara sertifikasi terhadap tanah wakaf yang berada di bawah tanggungjawabnya. Hal tersebut agar memperjelas status kepemilikan dari tanah wakaf tersebut. ${ }^{5}$

Namun, sekalipun telah ditentukan dalam Pasal 32 UU No. 41 Tahun 2004 maupun Pasal 12 ayat (1) PP Nomor 42 Tahun 2006 yang mengharuskan PPAIW atas nama nazhir untuk mendaftarkan tanah wakaf tersebut, masih banyak di Indonesia tanah wakaf yang belum didaftarkan, sehingga menimbulkan sengketa tentang tanah wakaf tersebut baik antara wakif dan nazhir itu sendiri maupun antara ahli waris wakif dengan nazhir. Akibat tidak didaftarkannya tanah wakaf tersebut yaitu tanah yang telah diwakafkan tersebut tidak memiliki dasar hukum, sehingga dalam penyelesaian sengketa mengenai pemilikan tanah wakaf tersebut akan menemukan kesulitan, terutama dalam hal pembuktian.

Maka berkaitan dengan latar belakang tersebut, penulis akan membatasi penulisan yang berkaitan dengan: Bagaimana kedudukan tanah wakaf yang dikuasai oleh ahli waris?; serta Bagaimana jaminan kepastian dan perlindungan hukum dalam perwakafan bagi nazhir?

\section{METODE PENELITIAN}

Dalam rangka mendapatkan informasi untuk penelitian hukum ini, maka tipe penelitian yang digunakan penulis adalah penelitian secara normatif. Penelitian secara normatif yaitu penelitian dengan menggunakan pendekatan perundang-undangan dan menarik asas-asas hukum yang berkaitan dengan tanah wakaf, sertipikat wakaf dan ahli waris dari wakif. ${ }^{6}$ Sedangkan pendekatan masalah yang digunakan dalam penelitian hukum ini menggunakan pendekatan statute approach. Pendekatan statute approach dilakukan dengan menelaah semua undangundang dan regulasi yang bersangkut paut dengan isu hukum yang sedang ditangani. ${ }^{7}$

\footnotetext{
5 ibid.

${ }^{6}$ Salim H.S. (2010). Perkembangan Teori dalam Ilmu Hukum. Jakarta: PT Raja Grafindo Persada, h. 64.

7 Peter Mahmud Marzuki. (2011). Penelitian Hukum, Cetakan ke-11. Jakarta: Kencana, h. 93.
} 


\section{PEMBAHASAN}

\section{Pelaksanaan Wakaf di Indonesia}

Wakaf berasal dari bahasa Arab, kata benda abstrak (masdar) atau kerja (fiil) yang dapat berfungsi sebagai kata kerja intrasitif (fiil lazim) atau transitif (fiil mutaadi). Pengertian yang dipakai dalam tulisan ini yaitu kata kerja transitif. Secara sederhana dapat pula dikatakan bahwa wakaf menurut bahasa berarti "menahan harta" tidak dipakai oleh seseorang, tidak pula diizinkan untuk dikuasai. ${ }^{8}$ Sedangkan menurut Pasal 1 UU No. 41 Tahun 2004 wakaf adalah perbuatan hukum wakif untuk memisahkan dan atau menyerahkan sebagian harta benda miliknya untuk dimanfaatkan selamanya atau untuk jangka waktu tertentu sesuai dengan kepentingannya guna keperluan ibadah dan atau kesejahteraan umum menurut syariah. Pada Hukum Islam sendiri tidak ada konsep yang tunggal tentang wakaf karena terdapat banyak pendapat yang sangat beragam. ${ }^{9}$

Di Indonesia, peraturan tentang wakaf telah ada jauh sebelum Indonesia merdeka. Namun, seluruh peraturan tersebut belum mampu mencakup segala aspek mengenai wakaf. Sebelum adanya UUPA dan PP No. 28 Tahun 1977, masyarakat Islam masih menggunakan kebiasaan keagamaan, di mana perwakafan terjadi hanya secara lisan dan atas dasar kepercayaan. Hal tersebut terjadi karena umat Islam memandang bahwa wakaf merupakan amal soleh yang memiliki nilai mulia di hadirat Allah SWT, sehingga tidak perlu melalui prosedur administatif dan harta wakaf tersebut milik Allah SWT dan tidak dapat diganggu gugat tanpa seizin Allah SWT.

Oleh karena faham tersebut kini pengakuan mengenai validitas legal tentang harta wakaf berujung pada timbulnya sengketa pada tanah wakaf tersebut. Karena hanya dilakukan secara lisan, perwakafan tersebut tidak memiliki bukti tertulis tentang terjadinya perwakafan tersebut.

Setelah itu sebelum tahun 2000 wakaf telah lama dikelola oleh lembaga swasta dan perorangan. Namun masih terdapat hambatan, diantaranya adalah masih kurangnya pemahaman dan kepedulian umat Islam terhadap wakaf, SDM wakaf yang belum profesional,

${ }^{8}$ Helmi Karim. (1993). Fiqh Muamalah. Jakarta: PT Raja Grafindo Persada, h. 103.

${ }^{9}$ Abdurrahman. (1994). Masalah Perwakafan Tanah Milik dan Kedudukan Tanah Wakaf di Negara Kita, Jakarta: Citra Aditya Bakti, h. 15. dan pengaruh ekonomi global. ${ }^{10}$ Dalam usaha memaksimalkan pelaksanaan wakaf Kementerian Agama telah melakukan beberapa usaha langkah strategis, antara lain: ${ }^{11}$

1. Melahirkan Direktorat Pemberdayaan Wakaf, yang terdiri dari empat sub direktorat (Inventarisasi dan sertivikasi wakaf, penyuluhan wakaf, pengelolaan wakaf, dan bina lembaga wakaf).

2. Melahirkan Badan Wakaf Indonesia (BWI), sesuai amanat Pasal 47-61 UU No. 41 Tahun 2004.

3. Kemitraan usaha dan aliansi strategis, harus sesuai mengikuti sistem syariah yaitu musharakah atau mudharabah.

4. Kerjasama kebijakan dalam bidang ekonomipolitik.

5. Pengelolaan wakaf tunai.

Wakaf sendiri akan dianggap sah apabila telah memenuhi rukun dan syarat wakaf tersebut. Rukun dan syarat wakaf tersebut menurut figh yaitu: ${ }^{12}$

1. Waqif yaitu orang yang mewakafkan harta bendanya. Orang yang mewakafkan harta bendanya haruslah orang yang cakap. Kecakapan tersebut meliputi 4 kriteria yaitu: merdeka, berakal sehat, dewasa, tidak sedang di bawah pengampuan.

2. Mauquf 'alaih atau nazhir yaitu pihak yang menerima wakaf (orang atau badan hukum). Syaratnya yaitu: harus dinyatakan secara tegas pada waktu mengikrarkan wakaf, kepada siapa atau apa tujuan wakaf tresebut. Di mana tujuan wakaf tersebut haruslah untuk kepentingan ibadah.

3. Mauquf yaitu harta yang diwakafkan. Bendabenda yang diwakafkan adalah sah apabila memenuhi syarat berikut: benda tersebut harus mempunyai nilai, benda bergerak atau benda tetap yang dibenarkan untuk diwakafkan, benda yang diwakafkan harus tertentu (diketahui) ketika terjadi wakaf, benda tersebut merupakan milik si wakif.

${ }^{10}$ Direktorat Pemberdayaan Wakaf. (2006). Perkembangan Pengelolaan Wakaf di Indonesia. Jakarta: Direktorat Pemberdayaan Wakaf, h. 167-168.
${ }^{11}$ ibid.
12 ibid., h. 120. 
4. Shighat atau iqrar yaitu pernyataan atau ikrar wakif sebagai suatu kehendak untuk mewakafkan harta bendanya. Syaratnya antara lain: shighat harus munjazah (terjadi seketika), dan tidak diikuti syarat bathil, tidak diikuti pembatasan waktu, dan tidak mengandung suatu pengertian untuk mencabut kembali wakaf yang sudah dilakukan.

Abdul Ghofur Anshori menjelaskan bahwa secara penerapan tata cara perwakafan di Indonesia yaitu sebagai berikut: ${ }^{13}$

1. Perorangan atau badan hukum yang akan mewakafkan tanah miliknya (sebagai calon wakif) datang sendiri di hadapan PPAIW untuk melaksanakan ikrar wakaf. Bila calon wakif tidak dapat datang ke hadapan PPAIW karena suatu sebab, seperti sakit, sudah sangat tua dan lain-lain dapat membuat ikrar wakaf secara tertulis dengan persetujuan Kepala Kantor Departemen Agama Kabupaten letak tanah yang bersangkutan di hadapan dua orang saksi. Ikrar wakaf itu kemudian dibacakan pada nazhir di hadapan PPAIW.

2. Pada waktu menghadap PPAIW tersebut, wakif harus membawa surat-surat sebagai berikut:

a. Sertipikat hak milik atau tanda bukti pemilikan tanah lainnya seperti surat IPEDA (girik, petok, ketitir dan sebagainya).

b. Surat Keterangan Kepada Desa yang diperkuat oleh Kepala Kecamatan setempat yang menerangkan kebenaran pemilikan tanah dan tidak termasuk sengketa.

c. Surat keterangan pendaftaran tanah.

d. Izin dari Bupati/Kotamadya Kepala Daerah cq. Kepala Sub Direktorat Agraria Setempat.

3. PPAIW kemudian meneliti surat-surat dan syaratsyarat tersebut, apakah sudah memenuhi untuk pelepasan hak atas tanah (untuk diwakafkan), meneliti saksi-saksi dan mengesahkan susunan nazhir.

4. Menurut Dr. Abdul Ghofur, wakif mengikrarkan kehendak wakif itu kepada nazir yang telah disahkan. Ikrar tersebut harus diucapkan dengan jelas dan tegas dan dituangkan dalam bentuk tertulis. Bagi wakif yang tidak dapat

${ }^{13}$ Abdul Gofur Anshori. (2006). Hukum dan Praktek Perwakafan di Indonesia. Yogyakarta: Pilar Media, h. 83-84. mengucapkan ikrarnya, karena bisu misalnya, ia dapat menyatakan kehendaknya itu dengan isyarat, kemudian mengisi formulir ikrar wakaf. Kemudian semua yang hadir menandatangani blanko ikrar wakaf. Tentang bentuk dan isi ikrar wakaf tersebut telah ditentukan di dalam peraturan Direktoral Jenderal Bimbingan Masyarakat Islam tanggal 18 April 1978 No. $\mathrm{Kep} / \mathrm{D} / 75 / 78$.

5. PPAIW segera membuat Akta Ikrar Wakaf rangkap tiga dengan dibubuhi materai dan Salinan Akta Ikrar wakaf rangkap empat. Akta Ikrar Wakaf tersebut paling sedikit memuat: nama dan identitas wakif, nama dan identitas nadzhir, data dan keterangan harta benda wakaf, peruntukan harta benda wakaf dan jangka waktu wakaf. Selanjutnya selambat-lambatnya satu bulan sejak dibuatnya akta, akta tersebut wajib disampaikan kepada pihak-pihak yang bersangkutan. Disamping membuat akta, PPAIW membukukan semua itu dalam Daftar Akta Ikrar Wakaf dan menyimpannya dengan baik bersama aktanya.

Kementerian Agama telah melakukan usahausaha untuk menghindari sengketa mengenai perwakafan di Indonesia, namun masih banyak terjadi sengketa tentang wakaf di Indonesia. Hal tersebut diakibatkan masih kurang pahamnya masyarakat tentang konsep wakaf. Menurut Pasal 4 UU No. 41 Tahun 2004 wakaf bertujuan memanfaatkan harta benda wakaf sesuai dengan fungsinya. Sedangkan fungsi wakaf antara lain: ${ }^{14}$

a. Fungsi Ekonomi. Salah satu aspek yang terpenting dari wakaf adalah keadaan sebagai suatu sistem transfer kekayaan yang efektif.

b. Fungsi Sosial. Apabila wakaf diurus dan dilaksanakan dengan baik, berbagai kekurangan akan fasilitas dalam masyarakat akan lebih mudah teratasi.

c. Fungsi Ibadah. Wakaf merupakan satu bagian ibadah dalam pelaksanaan perintah Allah SWT, serta dalam memperkokoh hubungan denganNya.

d. Fungsi Ahlak. Wakaf akan menumbuhkan ahlak yang baik, di mana setiap orang rela mengorbankan apa yang paling dicintainya

${ }^{14}$ Athoillah. (2014). Hukum Wakaf. Bandung: Yrama Widya, h. 99. 
untuk suatu tujuan yang lebih tinggi dari pada kepentingan pribadinya.

Sedangkan fungsi wakaf menurut Kompilasi Hukum Islam Pasal 216 adalah mengekalkan manfaat benda wakaf sesuai dengan tujuan wakaf. Wakaf memiliki fungsi sosial dalam kehidupan masyarakat. Fungsi wakaf dalam konteks sosial misalnya dalam pembangunan kehidupan ekonomi masyarakat. ${ }^{15}$

\section{Sertipikat Tanah Wakaf sebagai Alat Bukti Penguasaan Tanah Wakaf}

Ketentuan mengenai benda yang dapat dijadikan wakaf yaitu benda yang merupaka status hak milik, harus bersih dalam artian tidak dibebani utang atau hipotek, tidak juga dibebani oleh bahan-bahan atau jaminan lainnya, tidak dalam sengketa maupun terikat dengan pihak manapun. Dalam Pasal 40 UU No. 41 Tahun 2004 menyebutkan bahwa harta benda wakaf yang sudah diwakafkan tidak boleh atau dilarang untuk dijadikan jaminan, disita, dihibahkan, dijual, diwariskan, ditukar atau dialihkan dalam bentuk pengalihan hak lainnya. Hal tersebut selaras dengan fatwa MUI yang juga menegaskan bahwa pada dasarnya tanah atau benda lain yg telah diwakafkan tidak boleh di jual-belikan, dihibahkan, dan/atau diwariskan. Sedangkan jika harta benda wakaf tersebut berubah fungsinya atau peruntukkannya maka nazhir harus kembali mendaftarkannya melalui PPAIW kepada instansi yang berwenang dan Badan Wakaf Indonesia. ${ }^{16}$

Seperti tanah, tanah merupakan bagian terpenting dari bumi dan tidak bisa dipisahkan dari kehidupan manusia terutama bagi masyarakat Indonesia. ${ }^{17}$ Tanah menempati kedudukan penting terlebih lagi bagi mereka yang tinggal di daerah pedesaan, yang menggantungkan hidupnya pada tanah. ${ }^{18}$ Berbagai jenis hak dapat melekat pada tanah dengan prosedur dan ketentuan sesuai dengan perolehan hak atas tanah tersebut, yaitu pendaftaran. Sebagai tanda selesainya

\section{5 ibid.}

${ }^{16}$ Junaidi Abdullah dan Nur Qodin. (2014). "Penyelesaian Perselisihan Wakaf dalam Hukum Positif". Jurnal Zakat dan Wakaf, 1(1), h. 41 .

${ }^{17}$ Nazira. (2017). "Dampak Pengabaian Sertifikasi Tanah Wakaf Terhadap Kepemilikan (Studi Kecamatan Meuraxa Kota Banda Aceh)". Skripsi. Fakultas Syariah dan Hukum Universitas Islam Negeri Ar-Raniry Darussalam Banda Aceh, h. 1.

${ }^{18}$ Adijani Al-Alabij. (2002). Perwakafan Tanah di Indonesia Dalam Teori dan Praktek. Jakarta: Raja Grafindo Persada, h. 1. pendaftaran hak atas tanah, maka dikeluarkan sertipikat hak atas tanah. Berdasarkan Pasal 19 ayat (2) UUPA, dinyatakan bahwa akhir dari kegiatan pendaftaran tanah di seluruh wilayah Indonesia yang diadakan oleh pemerintah, adalah pemberian suratsurat tanda bukti hak, yang mana berlaku sebagai alat pembuktian yang kuat. ${ }^{19}$

Dalam ketentuan hukum Islam dikenal ada banyak cara mendapatkan hak atas tanah. Dalam hukum Islam dikenal perolehan dan peralihan hak atas tanah melalui jual beli, tukar menukar, hibah, hadiah, infaq, sedekah, warisan, wasiat, wakaf, dan ihya-ulmawat (membuka tanah baru). ${ }^{20}$ Dari berbagai macam cara perolehan dan peralihan hak atas tanah dalam persepktif hukum Islam, wakaf termasuk salah satu cara perolehan dan peralihan hak yang berarti menahan harta yang bisa dimanfaatkan sementara barang tersebut masih utuh, dengan menghentikan sama sekali pengawasan terhadap barang tersebut dari orang yang mewakafkan dan lainnya. ${ }^{21}$

Salah satu harta benda yang dapat menjadi objek perwakafan adalah benda tidak bergerak seperti tanah. Dalam objek perwakafan yang berupa tanah, akan sangat erat hubungannya dengan agraria atau pertanahan. Untuk objek wakaf berupa tanah, tidak bisa hanya dilihat dari perspektif hukum Islam yang mengatur secara pokok mengenai wakaf, namun juga akan berhubungan dengan aturan-aturan yang telah diatur dalam ketentuan UUPA yang mengatur secara pokok mengenai tanah. ${ }^{22}$ Dalam ketentuan hukum agraria menganut paham bahwa semua hak atas tanah mempunyai fungsi sosial yang dapat mendatangkan manfaat bagi kepentingan umum, maka dalam hal tersebut masalah perwakafan tanah di Indonesia diakui dan dilindungi oleh negara yang dimuat dalam ketentuan UU No. 41 Tahun 2004 dan PP No. 42 Tahun 2006.

Menurut Mhd. Yamin Lubis dan Abd. Rahim Lubis, seperti dikuti oleh Umi Supraningsih

${ }^{19}$ Fani Martiawan. (2015). "Pembatalan Sertipikat Hak Atas Tanah Karena Cacat Administratif Serta Implikasinya Apabila Hak Atas Tanah Sedang Dijaminkan”. Jurnal Perspektif. Volume XX Nomor 2 Tahun 2015. Surabaya: Universitas Wijaya Kusuma Surabaya, h. 106

${ }^{20}$ Rachmadi Usman. (2009). Hukum Perwakafan di Indonesia. Jakarta: Sinar Grafika, h. 25.

${ }^{21}$ Wahbah Az-Zuhaili. (2007). Fiqh Islam Waadillatuhu. Damaskus: Darul Fiqri, h. 271.

${ }^{22}$ Nazira, op.cit., h. 3. 
menyatakan bahwa masalah perwakafan tanah mendapatkan tempat tersendiri dalam aturan hukum di bidang Agraria dan Pertanahan di Indonesia, hingga diatur tersendiri dalam ketentuan Pasal 49 ayat (3) UUPA. ${ }^{23}$ Harta wakaf pada prinsipnya adalah milik umat, dengan demikian manfaatnya juga harus dirasakan oleh umat, sehingga karena itu tanah wakaf merupakan tanggung jawab kolektif guna menjaga keeksistensiannya. Karena hal tersebut, di Indonesia sendiri dibutuhkan lembaga yang secara khusus bertugas untuk mengurus harta wakaf. Melalui UU No. 41 Tahun 2004, pengelolahan harta wakaf di Indoenesia mengharuskan PPAIW atas nama nazhir mendaftarakan harta benda wakaf kepada instansi yang berwenang. Selain UU No. 41 Tahun 2004, PP No. 42 Tahun 2006 dalam Pasal 12 ayat (1) menyebutkan bahwa nazhir wajib melakukan administrasi, mengelolah, mengembangkan, mengawasi, dan melindungi harta benda wakaf. Demi memperoleh kekuatan hukum atas tanah yang diwakafkan, harus dibuat suatu akta oleh Kepala KUA sebagai PPAIW yang disebut dengan AIW yang kemudian didaftarkan kepada BPN untuk diterbitkan sertipikat Tanah Wakaf.

Sertipikat sendiri menurut PP No. 24 Tahun 1997 merupakan tanda bukti hak yang berlaku sebagai alat pembuktian mengenai data fisik dan data yuridis yang termuat di dalamnya, sepanjang data fisik dan data yuridis tersebut sesuai dengan data yang ada dalam surat ukur dan buku tanah yang bersangkutan. Pendaftaran dan sertifikasi tanah wakaf sendiri didasarkan oleh beberapa peraturan perundang-undangan yang berlaku di Indonesia beberapa diantaranya, yaitu:

1. UUPA Pasal 19, 23, 32, dan 38;

2. UU No. 41 Tahun 2004;

3. PP No. 42 Tahun 2006; dan

4. PP No. 24 Tahun 1977.

Prosedur dan mekanisme dalam mendapatkan sertipikat tanah wakaf di Indonesia menurut hukum Islam yang menganjurkan setiap muslim yang memiliki harta kekayaan supaya tidak hanya digunakan untuk kepentingan sendiri, namun juga harus diperuntukkan untuk kepentingan umum harus dipenuhi oleh semua umat muslim. ${ }^{24}$

\footnotetext{
${ }^{23}$ ibid., h. 4.

${ }^{24}$ Abdul Halim. (2005). Hukum Perwakafan di Indonesia. Tangerang: Ciputat Press, h. 104.
}

Pendaftaran tanah wakaf ini sangat penting ditinjau dari ebberapa aspek salah satunya dari aspek hukum dan administrasi penguasaan dan penggunaan tanah wakaf yang sesuai dengan peraturan perundangundangan Agraria. ${ }^{25}$ Dalam kitab fiqh dijelaskan bahwa wakaf telah berlaku dengan sebuah lafazh, walaupun tidak diumumkan oleh hakim dan hilang miliknya wakif darinya walaupun barang tersebut masih ada di tangannya.hal tersebut diungkapkan oleh Imam Malik yang diikuti oleh Asy-Syafi'I dan Imam Ahmad. Namun pendapat Abu Hanifah berbebda dengan Imam Malik dan Asy-Syafi'I, beliau mengungkapkan bahwa tidak berlaku wakaf itu apabila tidak terlepas dari milik wakif, apabila hakim memberikan putusan dengan mengumumkan wakaf tersebut. ${ }^{26}$

Mengenai pendaftaran tanah wakaf dijaman Rasulullah tidak dijelaskan secara rinci, pendafatran tanah wakaf pada jaman itu hanya megacu ketentuan dalam Al-Qur'an Surah Al-Baqarah ayat 282. QS 1:282 bukan merupakan kekhususan mengenai pencatatan tanah wakaf, namun dalam ayat tersebut tersirat bahwa Islam juga menghendaki masalah wakaf dengan tertulis atau menggunakan administrasi serta saksi karena masalah wakaf juga termasuk yang telah diatur oleh Allah SWT. Lahirnya PP No. 42 Tahun 2006 seakan memberikan jawaban dari ketentuan yang tersirat dalam QS 1:282 atau juga dapat dikatakan sebagai implementasi terhadap ayatayat Tuhan. ${ }^{27}$

Sertipikat wakaf sendiri diperoleh dengan tujuan untuk mendapatkan kepastian hukum terhadap tanah wakaf tersebut. Menurut PP No. 42 Tahun 2006 termuat dalam BAB IV Bagian Kesatu Paragraf 1, Pasal 38 dan Pasal 39, yaitu:

1. Pendaftaran harta benda wakaf tidak bergerak dilaksanakan berdasarkan AIW atau APAIW;

2. Selain persyaratan sebagaimana yang dimaksud pada ayat (1) dilampirkan pula persyaratan sebagai berikut:

a. Sertipikat hak atas tanah atau sertipikat hak milik atas satuan rumah susun bersangkutan atau bukti pemilikan tanah lainnya;

b. Surat persyaratan dari yang bersangkutan bahwa tanahnya tidak dalam sengketa,

\footnotetext{
${ }^{25}$ Rahmadi Usman. op.cit., h. 90.

${ }^{26}$ ibid., h. 91.

${ }^{27}$ Abdul Halim. op.cit., h. 104.
} 
perkara, sitaan dan tidak dijaminkan yang diketahui oleh kepala desa atau lurah atau sebutan lain yang setingkat, yang diperkuat oleh camat setempat;

c. Izin dari pejabat yang berwenang sesuai dengan ketentuan peraturan perundangundangan dala hal tanahnya diperoleh dari instansi pemerintah, pemerintah daerah, BUMD/BUMN dan pemerintah desa atau sebutan lain yang setingkat dengan itu;

d. Izin dari pejabat bidang pertanahan apabila sertipikat dan keputusan pemberian phaknya diperlukan izin pelepasan/peralihan;

e. Izin dari dari pemegang hak pengelolahan atau hak milik dalam hal hak guna bangunan atau hak pakai diwakafkan di atas hak pengelolahan atau hak milik.

3. Pendaftaran sertipikat tanah wakaf dilakukan berdasarkan AIW atau PPAIW dengan tata cara sebagai berikut:

a. Terhadap tanah yang sudah berstatus hak milik didaftarkan menjadi tanah wakaf atas nama nazhir;

b. Terhadap tanah milik yang diwakafkan hanya sebagian dari luas keseluruhan harus dilakukan pemecahan sertipikat hak milik terlebih dahulu kemudian didaftarkan menjadi tanah wakaf atas nama nazhir;

c. Terhadap hak guna bangunan, hak guna usaha atau hak pakai di atas tanah Negara sebagaimana dimaksud Pasal 17 ayat (1) huruf $b$ yang telah mendapatkan persetujuan pelepasan hak dari pejabat yang berwenang di bidang pertanahan didaftarkan menjadi tanah wakaf atas nama nazhir;

d. Terhadap tanah yang belum berstatus hak milik yang berasal dari tanah milik adat langsung didaftarkan menjadi tanah wakaf atas nama nazhir;

e. Pejabat yang berwenang di bidang pertanahan kabupaten/kota setempat mencatat perwakafan tanah yang bersangkutan pada buku dan sertipikatnya.

Setelah didaftarkan dan dicatatkan pada Kantor BPN, dalam sertipikat tanah hak milik yang diwakafkan, maka tanah wakaf itu telah mempunyai alat pembuktian yang kuat berupa sertipikat tanah wakaf. Yang merupakan program nasional sebagai tanggung jawab pemerintah dan masyarakat. Pada dasarnya tujuan pendaftaran tanah sebagaimana yang dimaksud dalam Pasal 19 ayat (1) jo. Pasal 3 huruf (a) PP No. 24 Tahun 1997 yaitu untuk menjamin kepastian hukum dan perlindungan hukum. ${ }^{28}$

Ketentuan mengenai pendaftaran tanah yang diatur dalam Pasal 19 UUPA tidak hanya ditunjukan kepada pemerintah, tetapi ketentuan ini juga ditujukan kepada pemegang hak atas tanah. Dengan hal tersebut pengsertifikasian tanah wakaf sangat diperlukan guna memperoleh jaminan kepastian hukum dan perlindungan hukum terhadap tanah wakaf tersebut dan untuk menjaga kedudukannya sebagai tanah wakaf serta menjadi alat pembuktian yang kuat apabila suatu hari nanti terjadi persengketaan.

\section{Kedudukan Tanah Wakaf yang Dikuasai Ahli Waris}

Dalam literatur Fiqh Islam, kewarisan (almawarits kata tunggalnya al-mirats) lazim juga disebut dengan fara'idh, yaitu jamak dari kata fardh yang bermakna ketentuan atau takdir. Alfardh dalam terminologi syar' $i$ ialah bagian yang telah ditentukan untuk ahli waris. ${ }^{29}$ Menurut Pasal 171 (a) KHI, Hukum kewarisan adalah hukum yang mengatur tentang pemindahan hak kepemilikan harta peninggalan (tirkah) pewaris, menentukan siapa-siapa yang berhak menjadi ahli waris dan berapa bagian masing-masing. Para fuqaha (ahli fiqih) mendefinisikan hukum kewarisan Islam sebagai suatu ilmu yang dengan dialah dapat kita ketahui orang yang menerima pusaka, orang yang tidak menerima pusaka, serta kadar yang diterima tiap-tiap ahli waris dan cara membaginya. Defenisi tersebut menekankan dari segi orang yang mewaris, orang yang tidak mewaris, besarnya bagian yang diterima oleh masing-masing ahli waris, serta cara membagikan warisan kepada ahli waris. ${ }^{30}$

Pewaris sendiri dalam Pasal 171 (b) disebutkan bahwa pewaris adalah orang yang pada saat meninggalnya atau yang dinyatakan meninggal berdasarkan putusan Pengadilan beragama Islam, meninggalkan ahli waris dan harta peninggalan.

${ }^{28}$ Adrian Sutedi. (2008). Peralihan Hak Atas Tanah dan Pendaftarannya, Jakarta: Sinar Grafika, h. 116.

${ }^{29}$ A.M. Basalamah. (1995). Pembagian Waris Menurut Islam. Jakarta: Gema Insani Press, h. 33.

30 Rachmad Budiono. (1999). Pembaharuan Hukum Kewarisan Islam di Indonesia. Bandung: Citra Aditya Bakti, h. 1. 
Sedangkan ahli waris menurut Pasal 171 (c) KHI, ahli waris adalah orang yang saat pada meninggal dunia mempunyai hubungan darah atau hubungan perkawinan dengan pewaris, beragama islam dan tidak berhalang karena hukum untuk menjadi ahli waris. Dilihat dari segi asalnya waris berasal dari kata Arab, yaitu warits yang artinya yang tinggal atau yang kekal. Dengan begitu dapat diartikan bahwa waris berarti orang-orang yang berhak untuk menerima pusaka dari harta yang ditinggalkan oleh pewaris. $^{31}$

Menurut ketentuan hukum waris Islam, syarat seseorang dapat menjadi ahli waris yaitu: 1. Karena hubungan perkawinan; 2. Karena adanya hubungan darah; 3. Karena memerdekakan si mayit; 4. Karena sesama Islam; ${ }^{32}$

Menurut hukum Islam, seorang muslim yang meninggal dunia, dan jika ia tiak memiliki ahli waris sama sekali maupun ahli waris beragama Islam, maka harta warisannya diserahkan kepada Baitul Mal dan lebih lanjut dipergunakan untuk kepentingan kaum muslimin. ${ }^{33}$ Sedangkan apabila si mayit memiliki ahli waris yang meninggalkan agama Islam dengan kemauannya sendiri atau murtad, baik laki-laki maupun perempuan maka ia si ahli waris tersebut tidak berhak menerima warisan dari keluarganya yang beragama Islam tersebut. Begitu juga sebaliknya. Keluarga yang beragama Islam tidak berhak menerima warisan dari yang murtad tersebut. Sedangkan harta waris menurut Pasal 171 (e) adalah harta bawaan ditambah bagian dari harta bersama setelah digunakan untuk keperluan pewaris selama sakit sampai meninggalnya, biaya pengurusan jenazah (tajnis), pembayaran hutang dan pemberian untuk kerabat.

Di Indonesia masih banyak ditemukan sengketa mengenai tanah wakaf. Yang mana para pihak sengketa diantaranya adalah keluarga atau ahli waris dari pihak wakif dan juga nazhir. Dalam Pasal 62 UU No. 41 Tahun 2004 telah menentukan alternatif penyelesaian apabila terjadi sengketa yaitu diantaranya melalui musyawarah, mediasi, arbitrasi, dan jalan terakhir melalui pengadilan. Dalam hal terjadi sengketa dalam wakaf, dalam Pasal 49 UU No.

\footnotetext{
${ }^{31}$ ibid., h. 3.

32 Suhrawardi K. Lubis dan Komis Simanjutak. (2013). Hukum Waris Islam. Jakarta: Sinar Grafika, h. 55.

${ }^{33}$ ibid.
}

3 Tahun 2006 telah menyebutkan bahwa Pengadilan Agamalah yang berwenang menyelesaikan perkara wakaf antar umat Islam.

Sengketa tanah wakaf timbul akibat masih banyak ditemukan tanah wakaf yang belum memiliki sertipikat. Padahal, sertipikat tanah wakaf sangat penting guna membuktikan bahwa tanah milik dari wakif tersebut telah menjadi tanah wakaf yang diserahkannya kepada nazhir. Karena tidak memiliki sertipikat tanah wakaf tersebutlah tidak jarang ahli waris wakif meminta kembali tanah wakaf tersebut atau mengingkari adanya ikrar wakaf tersebut. Padahal pada Pasal 3 UU No. 41 Tahun 2004 telah secara tegas menyebutkan bahwa wakaf yang telah diikrarkan tidak dapat dibatalkan atau ditarik kembali. Selain itu menurut hadits Umar Ibnu AlKhattab tentang wakaf, bahwa harta wakaf tidak bisa diperjualbelikan, tidak bisa diwariskan, dan tidak bisa juga dihibahkan.

Dengan adanya penegasan dalam pasal tersebut dapat ditarik dilihat bahwa tanah yang telah diwakafkan tidak dapat dijadikan bagian dalam waris mewaris. Apalagi telah ada AIW, yang mana bukti telah terjadi perwakafan. Jika AIW saja dapat menjadi bukti, maka sertipikat tanah wakaf sudah pasti memiliki bukti yang kuat karena merupakan akta otentik yang dikeluarkan oleh BPN dan mendapat perlindungan dan memiliki kepastian hukum. Oleh karena itu, ahli waris yang menuntut untuk menarik kembali tanah wakaf tidak memiliki alas hak dalam melakukan perbuatan tersebut. Tanah wakaf yang mana telah memenuhi rukun dan syarat sahnya wakaf tanah tidak dapat ditarik atau tidak dapat dibatalkan yang mana telah ditegaskan dalam Pasal 3 UU No. 41 Tahun 2004.

\section{Jaminan Kepastian dan Perlindungan Hukum dalam Perwakafan bagi Nazhir}

Wakaf dalam hukum Islam merupakan suatu amal soleh yang memiliki nilai mulia di hadirat Allah SWT. Perbuatan hukum wakaf ini dapat diperkuat atau dibuktikan dengan adanya Akta Ikrar Wakaf (AIW) yang merupakan suatu akta otentik yang dibuat oleh PPAIW menurut Pasal 1 ayat (6) PP No. 42 Tahun 2006. Dengan adanya AIW tersebut maka tanah wakaf terebut tidak dapat diganggu gugat sekalipun oleh ahli waris selama tidak dibuktikan sebaliknya. Hal tersebut sejalan dengan bunyi Pasal 3 Undang- 
Undang No. 31 Tahun 2004 yang mengatakan bahwa wakaf tidak tidak dapat dibatalakan. Tetapi pada nyatanya tanah wakaf yang bahkan telah ada AIW masih diganggu gugat oleh ahli waris dari wakif yang menuntut untuk menarik kembali tanah wakaf tersebut karena merupakan bagian dari harta warisan yang ditinggalkan oleh wakif.

Jaminan kepastian hukum bagi nazhir yaitu melalui pendaftaran tanah wakaf sesuai dengan Pasal 32 UU No. 41 Tahun 2004 jo. PP No. 28 Tahun 1997 Jo. Permendaman No. 6 Tahunn 1997 yaitu sebagai beikut: ${ }^{34}$

1. Pasal 32 UU No. 41 Tahun 2004 disebutkan bahwa PPAIW atas nama nazhir mendaftarkan harta benda wakaf kepada instansi yang berwenang paling lambat 7 (tujuh) hari kerja sejak akta ikrar wakaf ditandatangani dengan dilampiri: sertipikat yang bersangkutan atau bila tidak ada boleh menggunakan surat-surat bukti kepemilikan tanah yang ada, salinan akta ikrar wakaf yang dibuat PPAIW dan surat pengesahan nazhir;

2. Kepala Kantor Pertanahan Kabupaten/Kota, setelah menerima surat permohonan dari PPAIW dan meneliti surat dan lampiran surat permohonan itu, mencatat perwakafan tanah milik tersebut pada buku tanah yang ada dikantornya dan pada sertipikat tanah yang diwakafkan itu dicatat beberapa hal sesuai dengan peraturan yang berlaku mengenai perwakafan tanah milik. Bila pengajuan permohonan itu bersamaan dengan permintaan pengesahan hak/konversi, maka pencatatan wakafnya baru dilakukan setelah sertipikatnya dikeluarkan. Bila yang diwakafkan itu sebagian dari tanah milik, maka terhadap bidang tanah itu harus dilakukan pemisahan terlebih dahulu sehingga masingmasing mempunyai sertipikat sendiri-sendiri. Jika nazhir terdiri dari kelompok orang, maka yang ditulis dalam buku tanah dan sertipikatnya adalah nama orang-orang dari kelompok tersebut disertai kedudukannya di dalam kepengurusan. Bila kelak ada anggota nazhir yang meninggal dunia, mengundurkan diri atau diganti, maka diadakan penyesuaian seperlunya, berdasarkan pengesahan susunan nazhir yang dilakukan oleh

${ }^{34}$ Abdul Ghofur Anshori. (2005). Hukum dan Praktik Perwakafan di Indonesia. Yogyakarta: Pilar Media, h. 85-86.
PPAIW. Jika nazhir itu Badan Hukum, maka yang ditulis dalam buku tanah dan sertipikatnya adalah nama badan hukum tersebut.

3. Setelah perwakafan tanah dicatat pada buku tanah dan sertipikatnya, maka Kepala Kantor Pertanahan Kabupaten/Kota setempat menerbitkan bukti pendaftaran harta benda wakaf dan menyerahkan sertipikat itu kepada nazhir yang wajib melaporkan halaman itu kepada PPAIW untuk dicatat dalam Daftar Akta Ikrar Wakaf.

4. Dalam hal harta benda wakaf ditukar atau diubah peruntukannya, nazhir melalui PPAIW mendaftarkan kembali kepada instansi yang berwenang (dalam hal ini Kepala Kantor Pertanahan Kabupaten/Kota) dan Badan Wakaf Indonesia harta benda wakaf yang ditukar atau diubah peruntukkannya itu sesuai dengan ketentuan yang berlaku dalam tata cara pendaftaran harta benda wakaf. Fungsi pendaftaran tanah wakaf pada pokoknya adalah untuk memperoleh jaminan kepastian hukum Dn perlindungan hukum mengenai tanah yang diwakafkan. Bila hal ini dilaksanakan dengan baik, maka ketertiban masalah perwakafan di Indonesia akan tercapai.

Perlindungan hukum bagi nazhir agar tidak digugat oleh ahli waris terbagi menjadi 2 bentuk yaitu: ${ }^{35}$

1. Perlindungna hukum secara preventif, yang bertujuan untuk mencegah terjadinya sengketa, kewajiban untuk membuat AIW tanah dan mendaftarkan AIW tersebut untuk diterbitkan sertipikat tanah wakaf serta memberitahukan kepada ahli waris.

2. Perlindungan hukum secara represif, yang bertujuan untuk menyelesaikan terjadinya sengketa, yang diperlukan guna mencari penyelesaian ketika telah terjadi benturan kepentingan.

\section{PENUTUP}

\section{Kesimpulan}

Kedudukan tanah wakaf yang dikuasai oleh ahli waris tidak memiliki dasar hukum. Karena menurut Pasal 13 UU No. 41 Tahun 2004 menegaskan bahwa wakaf dikelola, dikembangkan, diawasi dan

35 ibid. 
dilindungi oleh nazhir. Pasal 3 UU No. 41 Tahun 2004 telah secara tegas juga menyebutkan bahwa wakaf yang telah diikrarkan tidak dapat dibatalkan atau ditarik kembali. Selain itu menurut hadits Umar Ibnu Al-Khattab tentang wakaf, bahwa harta wakaf tidak bisa diperjualbelikan, tidak bisa diwariskan, dan tidak bisa juga dihibahkan. Dengan adanya penegasan dalam pasal tersebut dapat ditarik bahwa tanah yang telah diwakafkan tidak dapat dijadikan bagian dalam waris. AIW merupakan bukti telah terjadi perwakafan. Jika AIW saja dapat menjadi bukti, maka sertipikat tanah wakaf sudah pasti memiliki bukti yang kuat karena merupakan akta otentik yang dikeluarkan oleh BPN dan memiliki kepastian hukum. Oleh karena itu, ahli waris yang menuntut untuk menarik kembali tanah wakaf tidak memiliki alas hak dalam melakukan perbuatan tersebut. Tanah wakaf yang mana telah memenuhi rukun dan syarat sahnya wakaf tanah tidak dapat ditarik atau tidak dapat dibatalkan yang mana telah ditegaskan dalam Pasal 3 UU No. 41 Tahun 2004.

Jaminan kepastian hukum bagi nazhir dapat terjadi dengan cara pendaftaran tanah wakaf oleh PPAIW kepada instransi yang berwenang (BPN). Dengan didaftarkan maka akan diterbitkan sertipikat wakaf yang mana merupakan bukti autentik apabila terjadi sengketa. Dengan adanya sertipikat wakaf tersebut maka kedudukan wakif yang mana namanya tercantum dalam sertipikat wakaf tersebut telah dijamin oleh hukum dan dilindungi selama tidak dibuktikan lain atau sebaliknya.

\section{Rekomendasi}

Karena AIW dan Sertipikat Tanah Wakaf sangat penting guna menghindari sengketa, diharapkan agar pemerintah lebih berupaya lagi mensosialisasikan agar wakaf harus dilakukan di hadapan PPAIW dan didaftarkan untuk mendapatkan sertipikat tanah guna menghindari sengketa antara ahli waris wakif dengan nazhir. Dan diharapkan juga agar nazhir menggunakan tanah wakaf tersebut sesuai dengan peruntukan sebenarnya sesuai dengan mauquf'alih tanah wakaf tersebut.

\section{DAFTAR PUSTAKA}

\section{Peraturan Perundang-undangan:}

Undang-Undang Nomor 5 Tahun 1960 tentang Peraturan Dasar Pokok-Pokok Agraria,
Lembaran Berita Negara Republik Indonesia Tahun 1960 Nomor 104, Tambahan Lembaran Negara Noomor 2043.

Undang-Undang Nomor 41 Tahun 2004 tentang Wakaf, Lembaran Berita Negara Republik Indonesia Tahun 2004 Nomor 159, Tambahan Lembaran Negara Nomor 4459.

Peraturan Pemerintah Nomor 24 Tahun 1997 tentang Pendaftaran Tanah, Lembaran Berita Negara Republik Indonesia Tahun 1997 Nomor 59, Tambahan Lembaran Negara Nomor 3696.

Peraturan Pemerintah Nomor 25 Tahun 2018 tentang Perubahan atas Peraturan Nomor 42 Tahun 2006 tentang Pelaksanaan Undang-Undang Nomor 41 Tahun 2004 tentang Wakaf, Lembaran Berita Negara Republik Indonesia Tahun 2018 Nomor 93, Tambahan Lembaran Negara Nomor 6217.

\section{Buku:}

A.M. Basalamah. (1995). Pembagian Waris Menurut Islam. Jakarta: Gema Insani Press.

Abdul Ghofur Anshori. (2005). Hukum dan Praktik Perwakafan di Indonesia. Yogyakarta: Pilar Media.

Abdul Gofur Anshori. (2006). Hukum dan Praktek Perwakafan di Indonesia. Yogyakarta: Pilar Media.

Abdul Halim. (2005). Hukum Perwakafan di Indonesia. Tangerang: Ciputat Press.

Abdurrahman. (1994). Masalah Perwakafan Tanah Milik dan Kedudukan Tanah Wakaf di Negara Kita, Jakarta: Citra Aditya Bakti.

Adijani Al-Alabij. (1989). Perwakafan Tanah di Indonesia. Jakarta: Rajawali Press. (2002). Perwakafan Tanah di Indonesia Dalam Teori dan Praktek. Jakarta: Raja Grafindo Persada.

Adrian Sutedi. (2008). Peralihan Hak Atas Tanah dan Pendaftarannya, Jakarta: Sinar Grafika.

Athoillah. (2014). Hukum Wakaf. Bandung: Yrama Widya.

Direktorat Pemberdayaan Wakaf. (2006). Perkembangan Pengelolaan Wakaf di Indonesia. Jakarta: Direktorat Pemberdayaan Wakaf.

H. Taufik Hamami. (2003). Perwakafan Tanah (Dalam Hukum Agraria Nasional). Jakarta: Tatanusa. 
Helmi Karim. (1993). Fiqh Muamalah. Jakarta: PT Raja Grafindo Persada.

Juhaya S. Praja. (1995). Perwakafan di Indonesia Sejarah Pemikiran Hukum dan Perkembangannya. Bandung: Yayasan Piara.

Peter Mahmud Marzuki. (2011). Penelitian Hukum, Cetakan ke-11. Jakarta: Kencana.

Rachmad Budiono. (1999). Pembaharuan Hukum Kewarisan Islam di Indonesia. Bandung: Citra Aditya Bakti.

Rachmadi Usman. (2009). Hukum Perwakafan di Indonesia. Jakarta: Sinar Grafika.

Salim H.S. (2010). Perkembangan Teori dalam Ilmu Hukum. Jakarta: PT Raja Grafindo Persada.

Suhrawardi K. Lubis dan Komis Simanjutak. (2013). Hukum Waris Islam. Jakarta: Sinar Grafika.

Wahbah Az-Zuhaili. (2007). Fiqh Islam Waadillatuhu. Damaskus: Darul Fiqri.

\section{Jurnal:}

Fani Martiawan. (2015). "Pembatalan Sertipikat Hak Atas Tanah Karena Cacat Administratif Serta Implikasinya Apabila Hak Atas Tanah Sedang Dijaminkan". Jurnal Perspektif. Volume XX Nomor 2 Tahun 2015. Surabaya: Universitas Wijaya Kusuma Surabaya.

Junaidi Abdullah dan Nur Qodin. (2014). "Penyelesaian Perselisihan Wakaf dalam Hukum Positif”. Jurnal Zakat dan Wakaf, 1(1), h. 41.

\section{Skripsi:}

Nazira. (2017). "Dampak Pengabaian Sertifikasi Tanah Wakaf Terhadap Kepemilikan (Studi Kecamatan Meuraxa Kota Banda Aceh)". Skripsi. Fakultas Syariah dan Hukum Universitas Islam Negeri Ar-Raniry Darussalam Banda Aceh. 